\title{
An Analysis of Relationships on Domestic Service and Apprenticeship in The City of London, Based on Legal Records, 1672-1715
}

\author{
Kaiying Xin $^{1, *}$
}

\author{
${ }^{1}$ Beijing Jingshan School, Beijing, China \\ *Corresponding author. Email: KaiyingXin0925@outlook.com
}

\begin{abstract}
This research focuses on the relationship between masters/mistresses and their servants/apprentices in the city of London through the legal records from the Old Bailey Proceedings during the years of 1672 to 1715 . Assorted by the categories of offense, the research will examine the relationship shown from either point of view. Previous studies, especially in the late 20th century, had concentrated on the life experience of young servants as apprentices in their masters' households either in a shorter time interval (17-18th century) or through the whole early modern period, and the graphical scale is also different by authors. This research aims to explain the examined legal data by the failure of filling mutual expectations while attempts to draw an objective view on the master-employee relationship in the late 17 th and early 18 th century.
\end{abstract}

Keywords: domestic service, apprenticeship, early modern England

\section{INTRODUCTION}

Servants and apprentices had continuously been a common part of English households during the past centuries, which number came to be a significant part, especially in the urban population. A servant could be an agricultural worker, footman, steward, or maid, depending on the gender and the career branch he or she chose. The domestic servants addressed here, who began this career at mid-teens and usually with lower social status than their master and mistress, means specifically those who usually resided with their master and mistress and practice the work inside the household. They acted as assistant roles to the household, varied from fieldwork, cleaning, cooking, child-rearing, etc. The apprentices were the youths who usually did not have a close genetic relationship with the household members, but bounded to learn the trade in which the master of the household was professional. Compared to the servants, who could be at any age before they married, the apprentices were primarily the younger and began the training at around 14 years old and were predominantly male. The female apprentices were the rather small proportion of the groups, whose number only began to grow gradually in the late 17 th century. [1] As the wife and children in the family, both apprentices and servants were the subordinate part of the household, subjected to the patriarch's orders and teachings. It has been proved that many contemporary accounts urged the heads of the household to treat their servants and apprentices as their children, acting as loco parentis. [2]In turn, Ideally, the apprentices and servants were supposed to serve their master's household truthfully and dutifully. It is also notable that the masters and mistresses were "entitled to exercise 'moderate' personal correction" over them. Though they were meant to be treated as the children, servants and apprentices actually did more housework, attested to be by historian Stevenson Smith. However, the ideal assumption did not really work out. It was shown that apprentices sometimes suffer abuse, intensive beating, or starving from their masters, and the servants sometimes could not receive wages.[3] Servants and apprentices also seemed to play a disruptive role in households, by acting disrespectfully, i.e. dressing above their station.[4] The offensive behaviors from both groups were due to the dissatisfaction with the treatment gained in the relationship, added by the assumption that the offense was made possible by the immediate closeness of the household, meaning that the property and corporal damage was easy and reachable. In addition, most of the conflicts did not include 
physical violence and were marked by the choice of either participant to bring the court for resolution. In the City of London from 1672 to 1715, Apprentices and servants were not treated as members of the family, nor did they treat their masters/mistresses as such either. Due to this, both groups committed acts that deviated from the ideal relationships within a household. The closeness of the household facilitated the theft of movable property.

Therefore, this research aims to explore the relationship between the master, mistress, and their domestic servants and apprentices. The examination centers on the investigation will be based on the early records of the Old Bailey, the City of

London's central criminal court in the years of 1672 to 1715 .ranged from the 1670 s to the early 18 th century. The result will be restrained to the city of London since the records only cover the cases here. In order to uncover the major problems each group faced in this relationship, I will sort the cases by the defendants(master of the servants/apprentices) and the main pattern of the offense. I will categorize the cases by the name of offense, including theft, murder, damage to property, and sexual offense.

These four types, though varied in degree and details, cover the majority of the law-violating conducted within a master-servant/apprentice relationship.

\section{LEGAL CASES AS DATA}

There have been several works discussing the life of servants and apprentices in early modern England. The relationship between them and their master's household is always an important topic in these previous researches. Dr. Holmes's thesis on domestic servants and Professor Lane's book, concerning apprentices, two works I will be referring much in this essay, both have chapters focusing on their relationship with the masters and mistresses. A few studies have used public archives such as court cases, indenture details, and records in guilds when they deal with the problems within the member and their apprentices. Studies by Professor Wallis proved that the tie between the servantsapprentices group with their employers was looser than what we used to think. It has been shown that the breaking of a contract between masters and servantsapprentices was so prevailing that it was almost the most common situation if there were any problems in a relationship. But the canceling of contract, especially the indenture for the apprentices, did not often appear in the court. The company or the guild usually had an institution to deal with the disagreement after the indenture took effect, including the cancellation.[5] In fact, the high turnover of the apprentice-servants group was quite common. Most of the apprentices did not always live with their masters and mistresses. Even a long time absence was common among them. The rate of canceling indenture was also high throughout the whole term, which seems against the sense that the apprenticeship was a very precious opportunity.[2] The lower servants, such as cleaning maids, footmen, or grooms who received lower wages, were also flexible in their service. They changed their employers quite often and did not usually serve a household longer than 5 years, whereas the higher-ranked servants could be considered part of the family and served the family much longer.[7]

The criminal court cases are often used as materials to explore the malicious relationships in previous studies because they show both the number of conflicts in each category and the motives behind them, at least partially. They are effective at showing the general trend and overall condition of the negative side of the relationship and give the discovered trend an empirical sense. However, the court proceedings have their disadvantages such as single-side driven, such as conflicts rather than harmonious ones. This is attributed to that the criminal courts always deal with negative affairs and the limitation of the provided information. We do not know much other than what was strictly related to the case. The conflicts could certainly be triggered by some random chances, which means that not all of the information presents something closely related to the master-servants/apprentices relationship. Inevitably some disputes had never been reported nor brought to court. Not only because such disputes were considered domestic affairs, but the humiliating nature of some unharmonious, such as sexual offense, also repulsed the number of certain cases to be significantly lower than others. Sometimes the previous deeds of the defendants were shown to prove his/her certain characteristic or reputation, but it is rare and often incomplete. It's hard to know whether the criminal was a repeated offender, which might affect the court decision. We have no further information beyond the judgment, such as the influence on the future decision, or the reaction of the public. Such information might be found at local or national archives, but they will not be included in this study because of limited online access.

Overall, the bias can inevitably exist due to the nature of court proceedings and the limited access for me in materials.

Strict restrictions were set upon the apprentices from their indentures, such as being obedient, keeping the master's trade secret, never sneaking out of the shop without permission.[7] Rules for the servants were relatively more varied than the company or guild controlled apprenticeship since the rules were more personal rather than large scale controlled. For guild apprentices, certain characteristics were favored by their employers: sobriety, steadiness, diligence, and honesty 
often appeared in the contemporary writings concerning the qualities needed for servants.[2] However, both guild apprentices and household apprentices were required to be deference, and protect the master's interests as best as they could. These values were indeed met to some extent: even in the covered criminal cases in this research. $\mathrm{T}$, there were young apprentices killed by the intruder when he tried to defend his/her master's house, and also apprentice who captured the shoplifter of his master's shop after chasing through a long distance.

However, it is known that the reality was quite contrasted. In fact, the abuse from the master and deceiving from the servants and apprentices were commonly exist. The reason why this ideal model did not function very well, might be attributed to the inequality in the authority of each group. For example, the masters and mistresses were given the right to correct the apprentice's behavior, which had no clear limitation or boundary. It will be shown in the analysis later that the abuses were hardly revealed or thwarted unless the death happened. The domestic servants' situation was less controllable as that of the apprentices since servants lacked the same ironclad indenture which allowed more differences to occur. However, since the people in early modern society did heavily believe in the reputation, the less obedient servants would be suspected of committing a violent crime, or hard to find another job in the area where his or her "bad" reputation had been spread by the former household. On the other hand, the apprentices and servants with comparably good performance in the household would gain the master's trust that, may not always have good results. The absence of the master and mistress would give the remained servant a great chance of stealing the goods in the house. The retired servants had very less prospects, and could often fail to establish their own household after ending their career in domestic service.[12] This fear of uncertainty and the potential chance of getting profits that would help in financing their own household may also prompt them into stealing and runaway

Despite all these difficulties of practicing the ideal relationship, the conception of idealness would probably be marked into many people's minds at that period. It's possible that the inculcation lay more on the master's side, whereas the servants were less literate. The masters and mistresses expected total obedience from the servants and apprentices, and the latter, especially the youth, expected their master and mistresses to treat them as their own children with good care. This mutual expectation resonates with the broader view of Englishmen on the social hierarchy system, notably the customary right in which the ruler exchanges the deference and obedience from the ruled for a kind and just care. [4] This long-existing mindset influenced the functioning of any household. The possible variance would only more likely to occur by the differences of the profession or the position of the employees in the household, owing to the facts that the less prospective trades might result in the poorer living condition of the apprentices, and the occupation of the servants which usually decide how much contact would they receive directly from the master and mistress.

\section{MASTERS AND MISTRESSES}

The first reason that made the whole relationship tense was the overwhelming power the masters and mistresses held, which was easily abused. They were supposed to act as parents to their servants and apprentices, who in general were at a similar age as their real children. Thus they were given authority to "govern every aspect" of their life.[8] How parents should treat their children was already a vague topic and was constantly under debate. The servants and apprentices, in turn, were surely under this undefined ideal. When they imagined that their new master would take good care of them, the reality might come in the contrast.

The abusive masters have been discussed in previous studies that they were one of the reasons for the apprentices and young servants to run away. [6] When the relationship resulted in a malicious and abusive one, the outcome would no other to be the abused runaway or the death eventually happened. This because of the compelling authority held by the masters that the members of the household had no ability to thwart the abuse. William Leaner, a tailor, beat his apprentice John Churchporch to death, while his neighbors and a boy in his household witnessed him abusing the apprentice brutal. (details see appendix) Some household members were even forced to assist their master to abuse the child. Anne Hollis ordered two other girls from her house to hold her apprentice to stop her escape from her beating.

Judith Bayly killed her husband's apprentice Richard Tate by burning him with a hot iron but was acquitted because her husband Edward was the major who first began to abuse this boy, burning him with a heated iron spindle, while Judith "only" assisted him and asked him to abuse the child more.

The masters and mistresses' compelling authority was also reflected in the trials were servants and apprentices as defendants. Children were instructed, by force or not, by their masters to commit crimes whether they know it was wrong or not. An unnamed boy stole a silver beaker and a spoon instructed by his master, who threatened to kill him if he was discovered. James Henry ordered his servant James Stockdale to open a bag of money and gave the money to him. The servants or apprentices were the sides brought to the court by whoever the plaintiff, but not the masters who instructed them to do. There was also a suspicious crime where the servants were brought to trial but were discovered as a 
malicious prosecution by there masters. A maid sued by her master for burning his house, whereas she proved the good education of herself, and the evidence demonstrated her innocent. It's possible that her master, despite she was an honest person, wanted to settle the compensation quickly of just attribute the crime to his servant as a scapegoat.

Masters and mistresses did not see apprentices and servants like their own children, instead, they treated them like criminals or pawns. In almost every case where the apprentices or young servants were beaten to death, their masters said it was on the purpose of correction rather than simply sadistic nature. Servants whose age might probably overall over were also considered as "childish" whose mental development did not fit the treatment as a grown person.[2] Therefore some inhumane ways of teaching and correcting were constantly done and might aggravate since the servants or apprentices were physically older, which probably made the masters thought they deserve severer punishment. The intent was not necessarily murder, but it was to correct the apprentices and servants' behavior. Elizabeth Deacon killed her servant girl Mary Cox due to suspected stolen money. Even though the girl kept denying the assertion, she interrogated her until the girl "confessed" the fact she would like to hear, but this did not stop her from killing the girl eventually. Some deaths were results of whimsical violence, which probably shows that these "small" but regular abuse means the masters' indifference of whether the correction would have the intended effect. Elizabeth Crosman killed her apprentice John Bret simply because he was playing with her son. She was drunk at the time, but this unwillingness to let her apprentice and son play together may firstly come with punishment, which finally causes death. A gentleman with unclear name as T.A. killed his wife's servant Joseph Loftus by striking several blows on his head for he did not clean the house as he expected. It is quite suspicious at first glance that "striking on the head" was a normal and acceptable way to correct the misbehavior. These strikes indeed caused severe injuries in the boy's skull which was discovered by the surgeons after his death. This violence by passion may be fostered by the belief of arbitrary power that some of the masters held.

\section{SERVANTS AND APPRENTICES}

The masters and mistresses were not the only individuals to break this relationship of mutual obligation. The servants and apprentices took advantage of their place in the household to make a profit, either in response to the mistreatment they received or on their own initiative. It was a common saying that the apprentices should not be trusted with valuable materials and dealing with wealthy clients.[6] The following cases are mainly related to stealing and property damage, whereas everything in the master's household was his family's belongings.

The theft was common in the examined data, in which about $81 \%$ of the crimes committed by the servants and apprentices were related to theft. The value of stolen items greatly varied, from a piece of linen to several thousand pounds sterling.

The motives were discussed in a former study that the main hypothesis is they wanted to imagine themselves in the same living statue as their masters and mistresses. Given the fact the retired servants usually found great trouble establishing their own household, often with a huge burden on married spouse since marrying always cause dismissal from the served household, and the servants often find their retired life so humble compared to that in service,[18] it was plausible that the servants wanted to gain profit from their masters as much as they could. Burning the master's property was another major crime by the servants and apprentices, although far less in number than theft, but the motives were harder to estimate since arson does not really bring profit to the incendiary compared to stealing.

However, this sense of "taking advantage" was not always considered unlawful among the servants. In fact, many of them believed that they had the right to take the left-out goods in their master's household. "They discarded candle ends, dripping, used playing cards, and so forth, and sold them to tradesman for their own profit, coast their masters dear over the year".[7] This impression was proved in the examined records here. Anne Burton took a tabby petticoat, a laced cravat, 5 silver spoons, a corner and quiof from the entrance of the master's door, and assume it was hers by right; Blanche Thomas took away 10 pounds money stored between her master's bed and mat. Money stored in the wrong place does not grant that they belong to whoever discovers them, especially in such cases where the servants were brought to court because of stealing these coins. In Burton's case, she claimed that she believes the items left in the entryway is "lawfully hers", which possibly suggests that at least some of the servants considered taking these left-out goods was the profit that their career granted.

Besides the mentioned cases in which the lack of clarity regarding the servant's deserved profit might be the cause of the theft, mere stealing was more common in the servants and apprentices. Among the cases related to theft, only 25 out of 128 involved in apprentices. The examples were too many and could hardly be assorted into limited categories due to the insufficient information the court cases provide. But among these cases where thefts with no other mentioning of different motives, the fault seems explicitly lay on the servants and apprentices' side since there is no mentioning of what the master's family had done wrong, or the 
employees did even receive good treatment. In these cases, there was less suspect and possibly good treatment from the masters and mistresses, while the servants and apprentice used this trust for their own profits. Some of them were fully trusted with the house or valuable goods, yet they took this opportunity to steal or let malicious people into the house. Richard Bushel, a trusted servant of Francis Annesley, consented John Crabb to make wine from his master's cellar and was accused by Crabb of asking him to forge a picklock key. Stephen Hemings trusted his servant Mary Adamson to keep the linen for him, yet she took these linens and sold them out. More stealing was done with a forged key to access the drawers or trunks in the house. Jane Jenkinson stole a silver taster and a silver straner from her master Thomas Lindsey with a false key from her master's drawer. Mary Nash took 8 out of 23 guineas from her master's drawer with a key, although the ownership of the key was not given. Stealing the goods from the master's personal storage using a key was naturally less conspicuous compared to violently breaking or grabbing things from the surface. Forged key possibly means the long-planning of the theft, or at least ruled out the chance of passionate theft. Many servants may not keep an attitude of duly service in the first place. Their expected relationship could be far less closely tied than what he society expected.

The damage to the master's property could be extended to larger property and people. House-burning, occurring more in the late 17 th century compared to the early 1700 s. It had a far fewer number of merely eight than theft despite it stood on the second common crime committed by the servants and apprentices. A widow's apprentice burnt her house, but at the court, he pointed out another person seducing him to set the fire. Daniel Groves, an apprentice to Mr. Foster, said it was a baker who tempted him to burn down the house. Since houseburning was hardly a prolific crime, such misdemeanors could incline to be passion-driven rather than selfseeking. Added by the fact that some also condemn others as a tempting source, it is assumable that the words of others intensify the discontent inside their mind.

exual offense by these employees was rare but still existed, their target, not surprisingly, was the household member other than the master and mistress. Thomas Benson, an apprentice, ravished his master's daughter who was only about 7 or 8 years old. Thomas Broughton assaulted his master's daughter who was under 10 at the time. Both were discovered by the parents when the girl was uncomfortable after the harm. It is hard to relate to any discontent among the apprentices in the household, but at least they did not consider themselves as dutiful members of the household who were supposed to see the children of the master as their siblings.
The servant-apprentice groups sometimes bore a dishonest reputation making them under the suspect of the masters when troubles occurred in the household. Many of them were suspected and brought to court simply due to things lost at the house, despite some of them had a good reputation among the neighborhood. Ellinor Burt was asserted of stealing 2 pairs of holland sheets, a black hat, two cornets, one coat from her master Mr.Tomson and his wife. The suspect came from his master and mistress that she did not close the door after making the bed in the chamber, and she did not return the key to them. John White, a servant to Henry Newman, was suspected by the later of stealing 4 pounds 5 shillings just because his master saw him from being very poor to "full of money" all of sudden. Francis Jorden was alleged of stealing silk from his master since the household "lost silk every day". twelve out of twenty masters or mistresses who committed murder against their employees were proved not guilty eventually, some through insufficient evidence, some through good reputation. The mistrust among the masters and mistresses was quite equal to the cases shown in the trust in the relationship.

There are certainly cases that could not be sorted into the discussed patterns. . Certainly an essential part of these is the cases that show good and dutiful relationships. When $\mathrm{n}$ the servant is under suspicion of the court, some masters would present to the court that he could prove the servant's reputation and innocence. John Rose was helped by his former master on conforming he did not steal the goods he carried. Ann Davis asked her master to prove that she had a good reputation, and he did tell the court that she had never done anything wrong before. It was also pretty common that the servants or apprentices caught the thieve from shoplifting. When John Manly, a mercer, got his shop robbed by Elizabeth Moor, his apprentice chased down the thief and handed her to the court. Elizabeth Vaughan, attempting to steal pewter dishes from John Toney's house while the latter was having dinner with the family, was spotted by the apprentice of the house then turned to the court. Another extreme example, William Fletcher fell into a fight with the constable and beadle because the latter wanted to enter his master's house. He was accidentally killed by the two in defense of the house.

There were also more examples representing the willingness to reconcile the relationship. A young apprentice to a smith asserted two men of stealing rabbits from his master, seemingly for making his master regain the trust to him since he had run away not too far ago. A more interesting but cruel one, a man named John Binlose showed great morose and begged pardon from his master after several attempts to kill him at night. Before this murdering attempt, he only wanted to rob money from his master's study since he couldn't hand in the money his father gave to the master. 
Combined with the examples which demonstrate the benevolent relationship, these experiences might suggest that there was indeed a possibility that the master-servant/apprentice relationship could be, if not ideal, a good one. Certainly, there were attempts to keep the relationship running in a positive way.

Similar situations of young servants betraying the comparably generous treatment from the master also occurred. William Lydall served Cavendish Weeden for 6 years, at the end of which he was given reward as to be bound to an apprenticeship to a ship carver. However, he turned down this offer and back to his former master's household in rag. Weeden provided him clothing and money, then ended up being robbed by him. Another apprentice named Edward Blewet stole 4 pounds sterling from his master Robert Falconer, who took him as an apprentice from charity six weeks ago. However, the record says that he "came to Falconer's door as a beggar", so it is hard to say that whether he was bounded to Falconer through the parish apprenticeship system or merely from the generosity of Robert Falconer.

Besides the pattern of the crime detail itself, the huge number of master and mistress bringing their servants and apprentices to the court, rather than dealing with it at home probably shows that they sometimes did not really consider the dispute between this relationship is a domestic affair, or they were not able to actually correct these misdemeanors by themself as "parents". Some of them brought their servants to court solely based on suspicion, which would be dealt with in the house if it was their child who conducted it. Of course, a few of them attempted to interrogate the youths by themselves, but we have seen disastrous results that the servant or apprentice was beaten to death through the "interrogation". It is plausible that since the mistrust was so prevailing that the masters found it too hard to trust the suspects' own word so bringing them to the court was the best answer available. Another factor worth mentioning is, only a few of the apprenticeship indentures explicitly allow the master to set physical correction toward the apprentice. This probably made the problem-solving process more complicated since some measures that the master adopted to shape his own child was no longer usable. [20] Unfortunately, there is no apparent discussion concerning how the contemporaries consider the fact that these supposed "domestic affairs" were brought to court. Nonetheless, Presumably, the extent of inclusion of the servants and apprentices to the household was a confusing question to the masters and mistresses as well.

It has been discussed in Jane Holmes'research on the 17th -18th-century master-servant relationship in England that these stealing happened partially due to the familiarity servants gained for their long time spent at the household. This claim is supported by the sources examined in this research as well: they knew where the valuable located: trunk, drawer, or even under the mat. Also, accommodations before the 19th century had less separation in rooms, which means that the master and mistress kept a long distance with their servants and apprentices. On the contrary, young employees even slept in the same room with the children of the household.[7] It was not until later the design of the houses keeping the servants away from the master's immediate family.[8] Besides, the frequent absence of apprentices living in the household might cause unnoticeable stealing or damage. [7] The closeness of household in the pre-19th century was also the probable reason for the continued physical abuse towards servants and apprentices. In addition, the annoying trivia the master experienced during the trade and the unfit lifestyle of the new employees both had the possibility of leading to inevitable hostility.[2]

Not all the misuse of the advantages came from the vague rules constituted for the servants. Some attempted for direct law-violation from this position, rather than conducted misdemeanor without careful consideration. A few thefts resulted from a very temporary relationship, in which the conflicts between the two groups hardly took place in such a short time. Sarah Carter stole a silver tankard, linen laces, and others from her master who she just been serving for three days. Ferdinando Fowler, a 12 years old boy, took 30 shillings from John Westwood who hired him to drive his carter-Westwood fell asleep on the carter in the night when he hires the boy and found both his money and Fowler gone the next day. Abigal Morgan, a maid just employed by the Aryes family a day before, was suspected of sneaking away 18 pewter plates, 2 tablecloths, a brass ladle, and a riding hood before the following morning.

\section{CONCLUSION}

The court decision is very essential since it reflects the standard and attitude of the people at a certain period, or at least reflect the attitude of the court. In the examined data, the most common factors are the inclination of favoring the masters and the reliance on reputation. Both physical abuse and sexual offense were hard to prove. The court usually let the involved masters go after his apprentice died for abuse because the abuse was not the direct cause. Edward Sea beat his apprentice William Ward to death, but the surgeons said none of the blows from Sea seemed to be causing the apprentice to die, so he was acquitted. John Gabriel killed Caleb Giver, seemingly his servant of 12 years, by kicking his thigh. Gabriel claimed that the boy died with a fever so it was his illness but not his violence causing the death. John and Hannah Basil were said to beat, assault, and starve their apprentice to death, but was acquitted as well with a short description that the 
boy died "of a natural cause". Even though it's possible that they could die of sickness since the mortality rate was high for children, the sickness of the child could overshadow abuse in the court judgment despite the evidence of abuse exists. In fact, "the majority of masters accused of murdering their apprentices were acquitted or only lost the premium".[2] This further extended an explanation that the "abuse" in our view was acceptable at that time. The standard of correction largely varied and was constantly in debate. The court, being a legal institution rather than moral, probably had no involvement in such a "familial" affair. There could be a far larger number of abusing never come to light since they did not result in death.

The preference of reputation lay equally on both masters and servant-apprentices. The defendants could be released by proving their good reputation by whoever they found if the evidence was insufficient. Many servants and apprentices got away from prosecution with their good record and education. A maid was released from the assertion of burning her master's house since she "was of very good reputation", and "well educated in the Protestant Religion".(Source, year/page) Ann Wood was charged with stealing a Pillow Bere and a Silk ribbon from her master John Yowle and his wife. However, she was proved honest by her friends and received approval from her former serving household of being a very good servant. On the contrary, the mistresses who charged her had the bad reputation of wage-delay and passionate temper. Naturally, the court released Anne Wood. William Forest was acquitted of stealing masquets from Thomas Sander because the witness who charged him was of a bad reputation, and was said to deal with Forest of embezzling the guns of the shop since he was the apprentice of Sanders. Edward Sea, a master who beat his apprentice to die, had a reason for being pardoned because 20 witnesses said he was not passionate and did not beat children so often.

As discussed above, these offensive cases can be explained by various factors, among which most notable are the general over-exertion of the master's authority and the lack of dutifulness of the servants and apprentices. The masters and mistress expected their apprentices and servants to be dutiful and serve them, but in fact, servants were thinking of how to sneak off with the household's goods. The apprentices and servants wanted to be guided and treated kindly and justly, whereas the masters and mistresses used them wrongly or abusively. This mutual failure of fulfilling the ideal may not occur coincidentally in the same household, but the sense of mistrust and fear of uncertainty was widespread, leading to a vicious cycle where both sides constantly remaining in mistrust and suspicion. We do not know who violated the contract in the first place, and where or when this common failure began. The ideal only based on a fragile foundation where any action that made any side felt violated and uncomfortable--would destroy the whole tranquility.

\section{APPENDIX}

1) Old Bailey Proceedings Online, July 1681, trial of William Leaner (t16810706-3)

2) Old Bailey Proceedings Online, May 1686, trial of Ann Hollis (t16860520-2).

3) Old Bailey Proceedings Online , January 1692, trial of Judith Bayly (t16920115-7).

4) Old Bailey Proceedings Online, October 1674, trial of Little Boy Master (t16741014-3)

5) Old Bailey Proceedings Online, December 1684, trial of James Stockdale (t16841210-49).

6) Old Bailey Proceedings Online , April 1679, trial of Maid (t16790430-5).

7) Old Bailey Proceedings Online, February 1690, trial of Elizabeth Deacon (t16900226-1).

8) Old Bailey Proceedings Online , December 1693, trial of T - A - (t16931206-36).

9) Old Bailey Proceedings Online, December 1690, trial of Anne Burton (t16901210-37).

10) Old Bailey Proceedings Online), January 1681, trial of Blanch Thomas (t16810117-14).

11) Old Bailey Proceedings Online, December 1712, trial of Richard Bushel John Crabb (t1712121048).

12) Old Bailey Proceedings Online, December 1714 , trial of Mary Adamson (t17141209-57).

13) Old Bailey Proceedings Online ), April 1708, trial of Jane Jenkinson (t17080414-9).

14) Old Bailey Proceedings Online, April 1715, trial of Mary Nash (t17150427-2).

15) Old Bailey Proceedings Online, June 1679, trial of Lad (t16790605-7).

16) Old Bailey Proceedings Online, December 1689 , trial of Daniel Groves (t16891211-1).

17) Old Bailey Proceedings Online, October 1684, trial of Thomas Benson (t16841008-12).

18) Old Bailey Proceedings Online , January 1686, trial of Thomas Broughton (t16860114-16).

19) Old Bailey Proceedings Online , January 1687, trial of Ellinor Burt (t16870114-24)

20) Old Bailey Proceedings Online, September 1693, trial of John White (t16930906-53). 
21) Old Bailey Proceedings Online, July 1685, trial of Francis Jorden (t16850716-15).

22) Old Bailey Proceedings Online, February 1688, trial of John Rose (t16880222-19).

23) Old Bailey Proceedings Online, March 1704, trial of Ann Davis (t17040308-20).

24) Old Bailey Proceedings Online, December 1690, trial of Elizabeth Moor alias Cane (t16901210-31).

25) Old Bailey Proceedings Online, July 1696, trial of Elizabeth Vaughan (t16960708-50).

26) Old Bailey Proceedings Online, September 1684, trial of Richard Burton Martin Stevenson (t16840903-2).

27) Old Bailey Proceedings Online, January 1688, trial of Mark Gutton Joseph Veasy (t16880113-9).

28) Old Bailey Proceedings Online, January 1691, trial of John Binlose (t16910115-1).

29) Old Bailey Proceedings Online, January 1700, trial of William Lyddall (t17000115-20).

30) Old Bailey Proceedings Online (www.oldbaileyonline.org, version 8.0, 16 September 2020), January 1692, trial of Edward Blewet (t16920115-2).

31) Old Bailey Proceedings Online, July 1688, trial of Ferdinando Fowler (t16880711-19).

32) Old Bailey Proceedings Online , April 1714, trial of Abigal Morgan (t17140407-2)

33) Old Bailey Proceedings Online, April 1679, trial of Maid (t16790430-5).

34) Old Bailey Proceedings Online, May 1684, trial of Ann Wood, alias Scot (t16840515-22).

35) Old Bailey Proceedings Online, June 1715, trial of William Forest (t17150602-4).

36) Old Bailey Proceedings Online, May 1686, trial of Edward Sea (t16860520-22).

\section{REFERENCES}

[1] Gowing L. Girls on Forms: Apprenticing Young Women in Seventeenth-Century London. Journal of British Studies 201655 447-473.

[2] Lane J.(1996) Apprenticeship In England, 16501914. London: UCL Press.

[3] Smith SR. The Ideal and Reality: Apprentice-Master Relationships in Seventeenth Century London. History of Education Quarterly 198121 449-459.
[4] Marshall D. The Domestic Servants of the Eighteenth Century. Economica 192925 15-40.

[5] Rushton P. The Matter in Variance: Adolescents and Domestic Conflict in the Pre-Industrial Economy of Northeast England, 1600-1800. Journal of Social History 199125 89-107.

[6] Wallis P. Apprenticeship and Training in Premodern England. The Journal of Economic History 2008 68.

[7] Holmes J. Domestic Service in Yorkshire, 16501780. In Department of History: University of York, 1989.

[8] Meldrum T. Domestic Service, Privacy and the Eighteenth-century Metropolitan Household. Urban History 199926 27-39. 